\title{
Antiangiogenic therapy
}

T Avitabile

From de Senectute: Age and Health Forum

Catanzaro, Italy. 5-7 December 2009

A brief look at AMD and developments which have completely subverted the therapeutic approach to patients affected by this disease.

New therapies available include: monoclonal antibody inhibitors of VEGF (Peptaganib, Bevacizumab, Ranibizumab) with the protocols currently in use and a brief reference to new anti-angiogenic therapies that include: decoy of VEGF receptor (VEGF Trap, Small Interfering RNA based therapies, Bevasiranib and AGN211745, Sirolimus) and the VEGF cascade of tyrosine kinase inhibitors (Vatalanib, Pazopanib, TG100801, TG101095, AG013958 and AL39324).

Published: 19 May 2010

doi:10.1186/1471-2318-10-S1-L4

Cite this article as: Avitabile: Antiangiogenic therapy. BMC Geriatrics 2010 10(Suppl 1):L4.
Director department of Ophthalmology, Santa Marta Hospital, Azienda Policlinico-Vittorio Emanuele, University of Catania, Italy
Submit your next manuscript to BioMed Central and take full advantage of:

- Convenient online submission

- Thorough peer review

- No space constraints or color figure charges

- Immediate publication on acceptance

- Inclusion in PubMed, CAS, Scopus and Google Scholar

- Research which is freely available for redistribution

Submit your manuscript at www.biomedcentral.com/submit
C Biomed Central 